\title{
腎移植100例の経験
}

$\begin{array}{ccccc} & \text { 橋 } & \text { 中 } & \text { 保 } & \text { 男 } \\ & \text { 高 } & \text { 原 } & \text { 史 } & \text { 郎 } \\ \text { 兵庫県立西宮病院泌尿器科 } & \text { 加 } & \text { 藤 } & \text { 良 } & \text { 成 } \\ & \text { 小 } & \text { 田 } & \text { 剛 } & \text { 士 } \\ & \text { 永 } & \text { 野 } & \text { 俊 } & \text { 介 } \\ \text { 同腎移植センタ一 } & \text { 福 } & \text { 西 } & \text { 孝 } & \text { 信 } \\ & \text { 石 } & \text { 橋 } & \text { 道 } & \text { 男 } \\ \text { 大阪大学泌尿器科 } & \text { 市 } & \text { 川 } & \text { 靖 } & \text { 二 } \\ & \text { 井 } & \text { 原 } & \text { 英 } & \text { 有 } \\ & \text { 有 } & \text { 馬 } & \text { 正 } & \text { 明 } \\ & \text { 大 } & \text { 岡 } & \text { 啓 } & \text { 二 } \\ \text { 愛媛大学泌尿器科 } & \text { 藤 } & \text { 田 } & & \text { 潔 }\end{array}$

\section{CLINICAL EXPERIENCE OF 100 RENAL TRANSPLANTATION}

\author{
Yasuo Hashinaka, Shiro Takahara, Yoshinari Kato, Takashi Oda, \\ Shunsuke Nagano, Takanobu Fukunishi*, Michio Ishibashi**, \\ Yasuji Ichikawa**, Hideari Ihara**, Masaaki Arima**, \\ Keiji Ohoka*** and Kiyoshi Fujita*** \\ Department of Urology, Hyogo Prefectural Nishinomiya Hospital \\ *Renal Transplantation Center, Hyogo Prefectural Nishinomiya Hospital \\ ${ }^{* *}$ Department of Urology, Osaka University \\ ${ }^{* * *}$ Department of Urology, Ehime University
}

One hundred and six kidney transplants were perfomed at our clinic from February 1973 until December 1982. They consisted of 99 living related transplants and 7 cadaveric transplants. The total survival rate was $95 \%$ at 1 year and $89 \%$ at 5 year.

The graft survival rate in the living related transplant was $85 \%$ at 1 year and $73 \%$ at 5 year. On the other hand, the number of cadaveric transplant was only 7 and the graft survival rate was $51 \%$ at 6 month. The decrease of posttransplant serious complications resulted in good patient survival and graft survival in the living related transplant. No case with urological complications was led to graft loss or patient death.

Two factors, histocompatibility and pretransplant blood transfusion which would have an influence upon graft survival, were analysed. 5 year graft survival of no mismatch in HLA AB was $100 \%$, which was significantly higher than that of 1 or 2 mismatch $(\mathrm{p}<0.01)$. The correlation between pretransplant transfusion and graft survival of the living related transplantation was present at 1 year and 2 year graft survival, but was not at 5 year.

要旨：1973年 2 月より1982年12月までに当院で行った腎移植は生体腎移植99回(97例), 死体腎移植 7 回, 計106回である.今回これら症例の，（1）患者生存率，（2）移植腎生着率，（3）男女別生着率，（4）合併 症を集計し，同時に生体腎移植に括ける，(5) HLA-AB Locus の mismatch 数と生着率の関連，(6) MLC と生着率の関連，（7）術前輸血量の生着率におよぼす影響について検討した。 
（1）死体腎移植を含めた 104 例の患者生存率は 1 年 $94.9 \% ， 5$ 年 $89.1 \%$ であった.

（2）生体腎移植の生着率は 1 年 $82.5 \% ， 5$ 年 $73.1 \%$ であった。死体腎移植はわずか 7 例であるが, 6 カ月生着率 $51.4 \%$ であった。

（3）男女別生着率は 1 年および 5 年共女性が男性より有意に良好な成績を示した。

（4）泌尿器科的合併症は尿瘻など 5 例 (4.7\%) で全て手術的に治癒した。 また感染症により死亡した 症例はなかった。

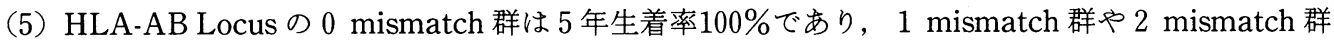
に比較して有意に良好な結果を示した。

（6）MLCの Low response 群は High response 群に比較して，有意差はなかったが良好な生着率を 示した。

（7）生体腎移植の生着率は短期（ 1 年拈よび 2 年）に扔いて，有意差はなかったが術前輸血量の多い 群ほど良好な成績を示した。

\section{I. 緒 言}

兵庫県立西宮病院泌尿器科㧍よび腎臟移植センター では 1973 年 2 月の第 1 例目の腎移植以来 1982 年 12 月末 までの約 10 年間に106回の腎移植を行った.今回これら 症例の成績と組織適合度の生着率におよぼす影響, 術 前輸血量と生着率の関連について検討し, 若干の文献 的考察を加觉た。

\section{II. 対象および方法}

対象は1973年 2 月より 1982年12月末までに腎移植を 行った104例（106回）で, 生体腎移植97例 (99回), 死 体腎移植 7 例 ( ちち米国死体腎 2 例，血縁提供者 1 例） である。それら症例の内訳と受者の原疾患, 受者扣よ び提供者の年龄分布, 年次別推移は Table 1, Fig. 1, Fig. 2 の如くである.

Fig. 1 Age distribution

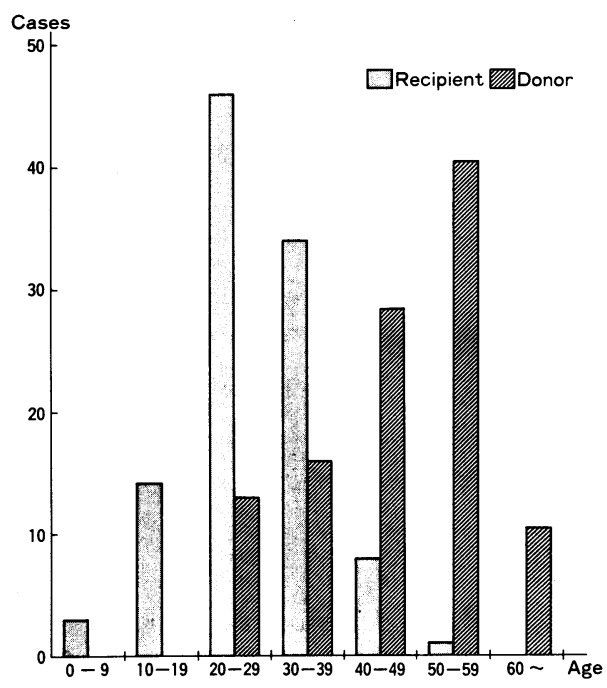

Table 1 Details of transplantation 1. Sex

Recipient: Male 62 cases, Female 44 cases

Donor : Male 39 cases, Female 67 cases

2. Donor relationship

Father 22 cases

Mother 45 cases Living 99 cases

Sibling 32 cases

Cadever

7 cases

3. Original disease

Glomerulo nephritis 96 cases

Pyelonephritis 3 cases

Polycystic disease 3 cases

Others 4 cases

Fig. 2 Graft number

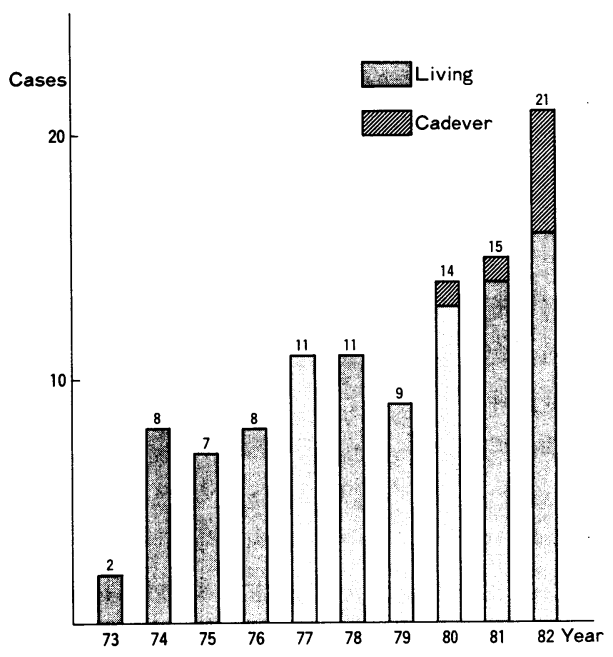

術前組織適合性検査としては $\mathrm{ABO}$ 型, $\mathrm{Rh}$ 型, Lewis および P 型, HLA-ABC, HLA-DR, リンパ球混 合培養 (MLC), T・B クロスマッチ(Donor specific 招 よび Panel cell)を行っている. 
Living Donor Nephrectomy は竹内ら ${ }^{1)}$ が報告した 方法で行い, 摘出腎の潅流はハルトマン液にプロカイ ン，ヘパリン，マンニットール，プレドゾロンを混じ た液にて行っている。

免疫抑制療法は Azathioprine と Steroid (Methylprednisolne, Prednisolne）を基本としている. Azathioprine は術前 2 日目より $2 \sim 3 \mathrm{mg} / \mathrm{kg} /$ day 投与し，術 後は白血球数や肝機能を示標として投与している. Steroid は Methylprednisolne 500mg/day で開始し, その後 Prednisolne に切り換光漸減して通常 $20 \mathrm{mg} /$ day 程度を維持量としている. Acute rejection の際に は Methylprednisolne $の$ pulse therapy 500 1,000 $\mathrm{mg} /$ day の隔日投与, ALG $500 \sim 1,500 \mathrm{mg} /$ day の連日 投与を行っている。充た肝障害を認めた場合や Azathioprine にて著明な白血球減少症を発症した場合には Azathioprineの減量ないし中止と Bredenineへの切 り換えを行っている.

今回，（1）患者生存率，（2）移植腎生着率，（3）男 女別生着率，（4）合併症扣よび死亡原因について集計 した。すた組織適合度の移植成績におよぼす影響を検 討するため, (5) HLA-AB Locus の mismatch 数と生 着率の関連，また MLCの Stimulation index (S.I.) が 7 以下のものを Low response 群とし 7 以上のもの を high response 群として，(6) MLC と生着の関連に ついて統計学的に検討した。同時に術前輸血量の判明 した67例の生体腎一次移植症例を輸血量別に分け，(7) 術前輸血量の生着率に拈よぼす影響についても検討し た。生存率・生着率は全て actuarial survival rate で 示した.

\section{III. 結 果}

（1）患者生存率

死体腎移植 8 例を含めた 104 例の当院での患者生存 率と1981年度腎移植臨床登録集計報告 ${ }^{2)}$ とよる患者生 存率の全国平均を表わしたものが Fig. 3 である. 1 年 生存率は当院 $94.9 \%$, 全国平均 $81.2 \%$ であり, 5 年生 存率は当院 $89.1 \%$ ，全国平均 $68.1 \%$ である.

(2) 移植腎生着率

当院での生体腎移植99回の生着率と腎移植臨床集計 報告による1971年以降の生体腎生着率の全国平均を表 わしたものがFig. 4 である。 1 年生着率は当院 $85.2 \%$, 全国平均 $72.2 \%$ であり，5年生着率は当院 $73.1 \%$, 全国平均 $52.5 \%$ である.

死体腎移植は1980年11月 1 日より開始し現在までわ ずか 7 例であるが，一応生着率を計算してみると， 6
Fig. 3 Overall patient survival

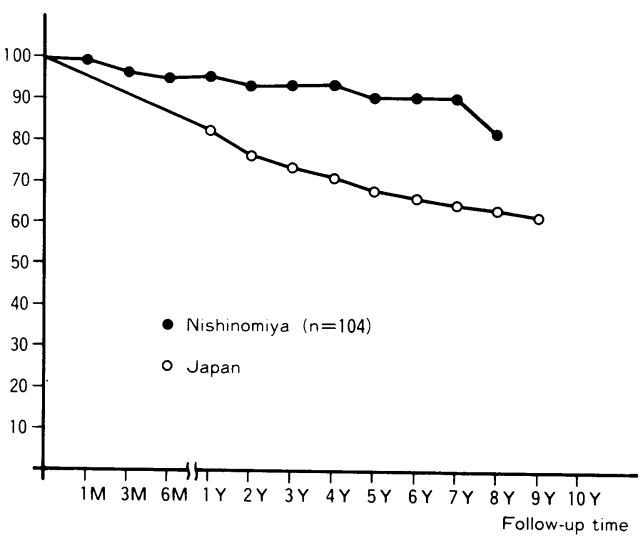

Fig. 4 Graft survival (living transplantation)

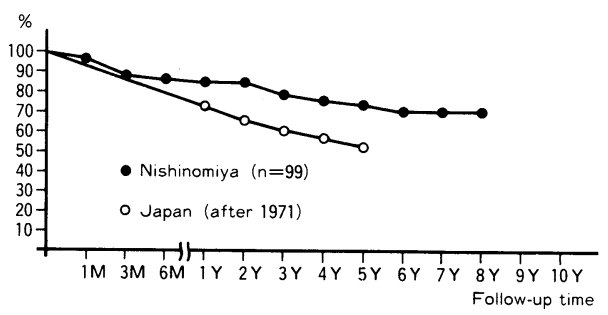

Fig. 5 Graft survival (living transplantation)

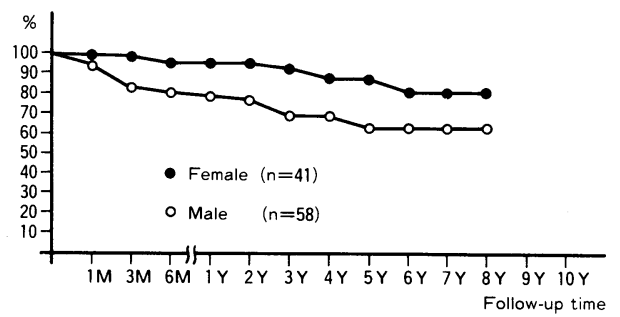

カ月生着率 $51.4 \%$ であった. Warm ischemic time は $0 \sim 60$ 分，平均 19 分であるが，米国腎を除くと平均 26 分であった。

（3）男女別生着率（生体腎移植）

生体腎移植の男女別生着率を検討すると， 1 年生着 率男 $77.9 \%$, 女 $95.0 \%$ であり， 5 年生着率男 $62.1 \%$, 女 $87.0 \%$ であった。 1 年执よび 5 年生着率共に女性の 方が男性より有意に成績がよかった $(\mathrm{p}<0.05) （$ Fig. 5)

（4）合併症 (Table 2)

腎移植後の合併症は Herpes zoster, 肺炎, 膿瘍など の感染症計26例で，次いで術前より肝障害を認めたも 
Table 2 Complications

$\begin{array}{lr}\text { O Infection } & \\ \text { Herpes zoster } & 8 \\ \text { Pneumonia } & 6 \\ \text { Abscess } & 3 \\ \text { Urinary tract infection } & 3 \\ \text { Pulmonary tuberculosis } & 2 \\ \text { Inflammation of the middle ear } & 2 \\ \quad \text { Appendicitis } & 1 \\ \quad \text { Sinusitis } & 1 \\ \text { O Hepatic dysfunction } & 21 \\ \text { O Fracture } & 20 \\ \text { O Diabetes mellitus } & 15 \\ \text { O Gastrointestinal bleeding or ulcer } & 6 \\ \text { O Cataract } & 6 \\ \text { O Scoliosis } & 6 \\ \text { O Leukopenia } & 4 \\ \text { O Urinary leakage } & 3 \\ \text { O Bone necrosis } & 3 \\ \text { O Lymphocele } & 2 \\ \text { O Abdominal hernia } & 2 \\ \text { O Alopecia } & 2 \\ \text { O Myocardial infarction } & 1 \\ \text { O Cerebral embolism } & 1 \\ \text { O Arterial embolism } & 1 \\ \text { O Graucoma } & 1 \\ \text { O Renal rapture } & 1 \\ \text { O Bladder stone } & 1 \\ \text { O Thrombocytopenia } & 1 \\ & \end{array}$

のを含めて術後一時的にしろ $\mathrm{GPT}$ が $100 \mathrm{mU} / \mathrm{ml}$ 以上 になったもの 21 例である。整形外科的合併症としては 骨析 20 例，無腐性骨壊死 3 例である．骨折は殆んどが 肋骨骨折で, 無症状に経過しレ線によって初めて診断 され，移植腎機能良好のものでは自然に化骨形成を起 し治癒している，尿路感染症を除いた泌尿器科的合併 症は疗瘦 3 例, リンパ囊腫による尿管閉塞 1 例, 膀胱 結石 1 例であるが，これらは全て手術的に治癒し Graft loss の原因にはなっていない.

死亡症例は計 9 例で，そのらち移植と関連したと思 われる 7 例の死因は, 胃十二指腸潰瘍穿孔ないし穿通 2 例, 消化管出血, 心筋梗塞, 肺梗塞, 脳梗塞, 劇症 肝炎各 1 例であった。 7 例中慢性拒絶反応にて透析再 導入後に消化管出血で死亡した女性 1 例を除いて全て 男性が死亡して抢り，また殆んぞの場合 Graft functioning の時期に合併症を起こしている.

(5) HLA-AB Locus の mismatch 数と生着率の関 連（生体腎移植）（Fig. 6)

0 mismatch 群 $(\mathrm{n}=25)$ と 1 mismatch 群 $(\mathrm{n}=36)$ および 2 mismatch 群 $(\mathrm{n}=37)$ を比較すると， 1 年お よび 5 年生着率に於て 0 mismatch 群が有意に 1 mismatch 群や 2 mismatch に比較して良好な成績を 示した $(\mathrm{p}<0.01)$.また 1 mismatch 群と 2 mismatch 群との間には 1 年执よび 5 年生着率ともに有意差を認
Fig. 6 Graft survival (living transplantation) and HLA-AB matching

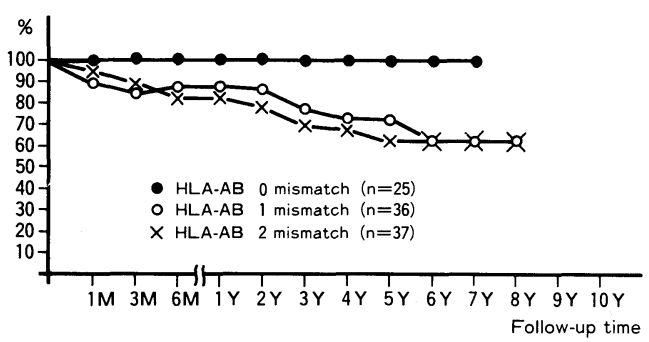

Fig. 7 Comparison of graft survival and mixed lymphocyte culture in 49 cases of living transplantation

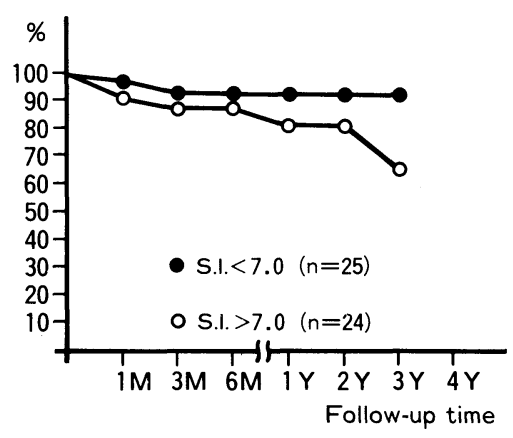

Fig. 8 Survival of first living grafts by volume of pretransplant transfusions

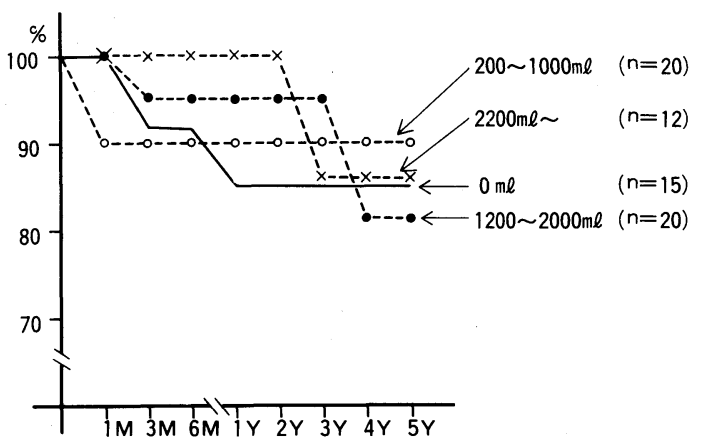

めなかった。

（6）最近の生体腎移植49例の MLC と生着率との関 連 (Fig. 7)

Low response 群 $(\mathrm{n}=25)$ と High response 群 $(\mathrm{n}=$ 24）と比較すると, Low response 群が High response 群に比較して良好な結果を示したが，有意差は認めな かった。

（7）術前輸血量と生着率の関連 
術前輸血量の判明した 67 例の生体腎一次移植の生着 率と術前輸血量との関連を調べると, 1 年执よび 2 年 生着率に於て輸血量の多い群の順で成績が良好であっ た.しかし有意差は認められなかった(Fig. 8).

またそのうち， 0 mismatch を除いた HLA-AB 1 mismatch 怙よび 2 mismatch の計49例にしぼって調 べても，同様に 1 年扣よび 2 年生着率に於て輸血量の 多い群注ど良好な生着率を示した。しかし，有意差は 認められなかった。 5 年生着率では輸血量との間に何 ら相関を認めなかった。

\section{IV. 考 察}

腎移植は慢性腎不全に対する治療法として本邦でも ようやく定着しつつある. 1981年度には356回の腎移植 が施行され，1981年12月末までに計2,059回（生体腎 1,701回，死体腎358回）となり，そのうち1,059例が現 在機能維持している2). しかしながら, 米国とカナダの 登録集計では1975年から1982年の間に約 23,000 回の腎 移植が行われ, 最近では年間扣よそ3,500回の腎移植が 行われている3 ${ }^{3)}$. 現在本邦では約 4 万人の慢性腎不全 患者が血液透析をらけ，年間 $4,000 \sim 5,000$ 人の患者発 生が認められている。血液透析の普及度や透析患者の 移植希望者に比較して，本邦での腎移植が如何に少い かがうかがい知れよう。

当院では1973年 2 月に最初の腎移植を施行して以来 約 10 年間に 100 例を越す腎移植を行ったが, 死体腎移植 7 例を含めて 1 年生存率 $94.9 \%, 5$ 年生存率 $89.1 \%$ で あった。 また生体腎移植 1 年生着率 $85.2 \% ， 5$ 年生着 率 $73.1 \%$ といずれも良好な結果を示した。生存率がよ かった最大の要因は，腎移植後の死因のうち最も多い とされる敗血症による死亡例がなかったことであろ 5.また HLA-AB 0 mismatch の 5 年生着率 $100 \%$ に みられる様に外科的合併症により Graft lossに至った ものが全くなかったことが生着率良好の要因と考兄ら れる。

男女別生着率に於て女性が男性より有意に成績がよ かった最大の要因は，透析再導入後死亡した女性一人 を除いて死亡例が全て男性であり，乙かもその大部分 が Graft functioning の時期に合併症を起し死亡して いるためである.これら移植と関連した死亡例は, 我々 が移植を開始した 38 例目までのものであって，現在で は死亡例は皆無である。

腎移植に伴う合併症としては感染症・肝障害・糖尿 病・消化管出血ないし潰瘍, 骨折および無腐性骨壊死 などの整形外科的合併症, 外科拈よび泌尿器科的合併
症，白内障・緑内障などの眼科的合併症があげられる． これら多方面の領域にわたった合併症に対しては早期 に診断し，免疫抑制剂の減量ないし中止を含む早期治 療が重要であることは勿論であるが，その為には関連 各科との協力体制が肝要である，術後一時的にしろ肝 障害を認めたものは21例であり，このうちかなりの症 例は術前より肝障害を有していたと考兄られた。これ らの症例に対して我々は内科医の協力により積極的に 腹腔鏡・肝生検を施行している。肝障害症例に対して はAzathioprine の減量ないし中止と Bredinineへの 切り換えを行い, 肝障害改善傾向が認められた4)5). 外 科的合併症のうち頻度が最も高く, Graft loss や patient loss に連なりやすいとされる泌尿器科的合併 症は 5 例 (4.7\%) で全て手術的に治癒し得た ${ }^{6)}$.このこ とは尿路系の手術に精通した外科医である泌尿器科医 が移植に携わるべきことを示していると思われる，移 植術後の感染症の多くは日和見感染であって複雑な病 像を呈し, 死体腎移植ではさらに Donor からの感染な ぞ種々の不利な条件が増大する，当院での肺炎・膿瘍 などの感染症は計26例であるが，感染症のため死亡し た症例は幸いなかった。丁度当院で腎移植を開始した 時期に新館が建設され，院内感染が抑兄られたことが 一因かもしれない。

一般的に腎移植の生存率・生着率は向上の傾向にあ り, これらの要因としては血液透析療法の普及と進歩 がまずあげられる．次いで HLA typingやCross match 等の Histocompatibility test の確立がある. 当 院での HLA-AB 0 mismatch 群の生存率・生着率は 100\%であって, 当然のことながら 1 mismatch 群打よ び 2 mismatch 群と比較して有意に良好な成績を示し た。むた MLCの Low response 群と High response 群を比較しても, 有意差はなかったものの Low response 群が良好な成績となった。これらの結果は特 に生体腎移植 (血縁提供者) に於ける HLA-AB の重要 性を再確認したものと言える。一方，死体腎移植に於 ては HLA-AB の matching は10 20\%程度の生着率 の改善しか示さないとされ7), HLA-DRの合致が成績 との相関上重要視されている ${ }^{8)}$. 我々も HLA-DRの合 致を最重要視しているが，死体腎移植の場合には死体 腎摘出時に於ける Donor の腎機能の影響が大きくこ れに加味される. 法的にも脳死の状態で, Heart beating で摘出可能な欧米と比較して, 本邦では提供者も 少くまた死戦期の長い条件でしか摘出できないのが現 状である。 
従来, 術前輸血はPreformed antibodyを形成し移 植に関して不利な因子と考兄られてきた.しかし, 1973 年 Opelz らが術前輸血量に比例して死体腎生着率は 良好となると報告し ${ }^{9)}$, 以後輸血量と生着率に関して 種々検討されている．生着率向上のメカニズムについ ては今だ不明なものの，一般に術前輸血は生着率向上 因子として考只られてきている，我々の成績もこれら の報告と合致するものであって， 1 年および 2 年では 有意差は認められないものの輸血量の多い群ほど成績 が良好な結果となった。しかし，長期（5 年）では輸 血量と生着率には相関を認めなかった。長期観察例は 例数も少なくなり，現時点での結論は差し控えたい。 輸血の種類や時期, 術中輸血量などに関して数施設で の集計報告もされているが(10), 我々も術後の Donor リ ンパ球に対する抗体の出現パターンなど現在検討中で ある。また1980年 Salvatierraらが生体腎移植の MLC $\cdot$ high response 群に Donor specific transfusion （DST）を施行し，有意に成績が向上したと報告してい る11). 我々も16例にDSTを行っているが，DST の生 着率に拈よぼす影響についての検討は今後報告する予 定である.

最後に, 少なくとも生体腎移植に於ける当院の成績 そのものは欧米に勝るとも劣らないと考兄られる。 た The 13th Report of the Human Renal Transplant Registry $\left.{ }^{12}\right)$ そられるように, 死因の約 $2 / 3$ は Functioning graft に発生している. 従って現在の非特異 的免疫抑制療法の限界を十分認識して, 重篤な合併症 を起さないことが臨床医にとって移植術後管理上最も 留意しなければならない点であることを強調したい。 またそれによって Patient loss, Graft loss が減少し腎 移植本来の目的である慢性腎不全患者の生活の質の向 上が果せると思われる。

\section{V. 結 論}

1. 死体腎移植を含めた患者生存率は 1 年 $94.9 \%, 5$ 年 $89.1 \%$ であり, 生体腎移植生着率は 1 年 $85.2 \%, 5$ 年 $73.1 \%$ であった。

2. 移植後合併症は比較的少く, 特に泌尿器科的合併 症により Graft loss に至ったものはなかった。これら のことが生存率・生着率良好の要因と考えられた。

3. HLA-AB Locus 0 mismatch 群の生着率は $100 \%$ で, 1 mismatch 群抒よびび 2 mismatch 群に比 較して有意に良好な成績を示した。
4. 術前輸血は短期 ( 1 年乃至 2 年) では生着率に良 好な影響を与える因子と考えられた。

本論文の要旨は第71回日本泌尿器科学会総会に招いて発 表した.

\section{文献}

1）竹内正文, 高羽 津, 佐川史郎, 秋山隆弘, 有馬正 明, 栗田 孝, 永野俊介: Living Donor $\mathrm{Ne}$ phrectomy. 移植, 10, 17-20, 1975.

2）日本移植学会：1981年度腎移植臨床登録集計報 告. 移植, 17, 462-466, 1982.

3) Perdue, S.T., Terasaki, P.I., Cats, S. and Mickey, M.R.: Kidney transplantation treands from UCLA registry data, 1975-1982, Transplantation, in press.

4）高原史郎, 橋中保男, 大岡啓二, 永野俊介, 福西孝 信, 進土義剛, 雄原英有, 市川靖二：腎移植後肝障 害に対する Bredinin の効果. 移植, 17, 737-748, 1982.

5）福西孝信, 高原史郎, 橋中保男, 大岡啓二, 永野俊 介, 高田寛治, 市川靖二 : ブレデニン血中濃度と免 疫抑制効果. 移植, 17, 749-752, 1982.

6) 井原英有, 高川靖二, 永野俊介, 福西孝信, 石橋道 男, 有馬正明, 宇佐美道之, 佐川史郎, 岡田孝夫： 腎移植後の尿瘦. 移植, $13 ， 283-286,1978$.

7) Morris, P.J., Batchelor, J.R. and Festenstein, H.: Matching for HLA in transplantation, Brit. Med.Bull., 34, 259-262, 1978.

8) Morris, P.J. and Ting, A.: Studies of HLA-DR with relavance to renal transplantation, Immunological Rev., 66, 103-131, 1982.

9) Opelz, G., Sengar, D.P.S., Mickey, M.R. and Terasaki, P.I. : Effect of blood transfusions on subsequent kidney transplants, Transplant Proc., 5, 253-259, 1973.

10）橋本 勇, 稲生網政, 岩崎洋治, 葛西森夫, 柏木 登, 佐藤 博, 横山健郎, 松井武男, 岡 隆宏: 術 前輸血と生体腎移植成績。移植， 17，457-461, 1982.

11) Salvatierra, O. Jr., Iwaki, Y., Vinecenti, F., Amend, W., Potter, D., opelz, G., Terasaki, P., Duca, R., Hopper, S. and Feduska, N.: Incidence, characteristics, and outcome of recipients sensitized after donor-specific blood transfusion. Transplantation, 32, 528-531, 1981.

12) Advisory, committee to the renal transplant registry: The 13th report of the human transplant registry. Transplant Proc., 9, 9-26, 1977. （1983年 9 月 2 日受付） 